\title{
Analysis of Determination Factors Outcome of Livelihood of Farmer Post-Tsunami in Aceh
}

\author{
Adhiana $^{1}$, Nurasih Shamadiyah ${ }^{1}$, and Riyandhi Praza ${ }^{1}$ \\ \{adhiana@unimal.ac.id\} \\ ${ }^{1}$ Departement of Agribussiness, Faculty of Agriculture, Universitas Malikussaleh, Aceh, Indonesia
}

\begin{abstract}
Limitations of access and loss of various life assets caused by tsunami and conflicts in Aceh faced by farmers have an influenced to their survival. This research aims to analyze the model of determination factor outcome of livelihood of farmer post-tsunami in Aceh. The sample of this study was in Aceh Province covering five areas: Aceh Barat, Aceh Besar, Pidie Jaya, Bireun and Aceh Utara. The total sample for this study was 280 farmers using stratified random sampling method. This research uses primary data obtained by survey using quesioner and secondary data. Data analysis using qualitative and quantitative methods with Structural Equation Modeling. This model used as the final model for the construct of the outcome of livelihood of farmer's determination factors as it demonstrates a good model compatibility. Its also indicates that all loading factor values have above 0.5 and all probability values are significant at $\mathrm{a}=1 \%$. Its indicated that all indicators can explain the existing constructs.
\end{abstract}

Keywords: Aceh, Determination Factor, Farmer, Outcome of Livelihood, PostTsunami

\section{INTRODUCTION}

Post-tsunami Aceh has been faced with severe community poverty. Limited access and loss of life assets is a serious problem facing the poor in rural areas. Tsunami disaster has also changed the family structure in Aceh. But after going through the emergency period, rehabilitation and construction for more than 10 years with spent budget trillion IDR. The impact of the tsunami on economic infrastructure and social facilities is also quite severe. More than half of wharves or seaports, fish and shrimp ponds, rice millers, agricultural land, rice fields are damaged, and livestock loss [1].

The tsunami has also destroyed the source of income of a large number of families in Aceh, including most poor families who find it most difficult to recover from their losses. Many efforts have been made, especially in the rehabilitation of housing developments for tsunami-affected and conflict-affected populations, the development of general infrastructure, and improvements in the livelihood sector. Recovery in agriculture and fisheries has also led to the potential of fisheries and agriculture in Aceh to experience various improvements in several aspects. Although its impact on the wider economic recovery of the community has 
not been sufficiently significant and has not been able to provide stronger and stronger role for economic growth and income generation and welfare and sustainable community life [2].

The situation has resulted in the achievement of the livelihood of the community becomes increasingly crippled, especially the declining welfare and income of the community. The achievements of life are the outcomes and benefits that society wants in their lives. The sustainable life framework seeks to understand the various benefits of life according to the strategies, motivations, choices and factors that influence life's benefits so that it can be achieved optimally. This achievement is related to the priorities and motivations of the people in life, which they establish in their way of living conditions, since the achievements of life can only be understood by the size of society itself.

Examples of outcomes of livelihood in sustainability approaches are higher incomes, increased welfare, reduced vulnerability, better food sufficiency, more sustainable use of natural resources [3]. The achievement of this life result is also influenced by vulnerability, asset availability, and life strategy [3].

People and their families have a variety of life's achievements which very important, since the necessities of life and their inclusion in development programs are often influenced by motivation, and ideals of a life that they perceive as ideal. It also denied that the measure of welfare, or poverty alleviation in general is by increasing income alone. As an improvement to the model developed by [3], Ellis developed the model to show a more robust access function [4]. Therefore, it is necessary to analyze the validation of achievement factor of farmer's life after tsunami in Aceh by using SEM model with measurement model. The purpose of this research is to analyze the attestation of achievement factor of farmer's life after tsunami in Aceh.

\section{METHODOLOGY}

\subsection{Population and Data Types}

The population of this research is the farmers in Aceh post tsunami which covers five districts of West Aceh, Aceh Besar, Pidie Jaya, Bireun and Aceh Utara. Sampling was done purposively, and the sample size was 280 farmers. Types of data used are qualitative and quantitative data, and data sources are primary and secondary data. Primary data is crosssection data collected through direct observation and interview conducted by using questionnaire at farmer in research area and secondary data obtained from related institution

\subsection{Data Analysis}

The analytical tool used for this study is the Confirmatory Factor Analysis (CFA) model contained in SEM This factor validation analysis (CFA) is used to test the measurement model [5] .This analysis it will be known whether existing indicators can explain a construct [6]. This analysis will be conducted to test each known asset variable dimension based on previous studies The maximum likelihood method is used to estimate 12 indicators of 4 construct the achievement of life outcomes established Figure 2 shows the factor validation model for the achievement of life outcomes.

Data analysis is done by using model of determination (Measurement Model) which is in Structural Equation Modeling (SEM). The determination model known as the factor validation analysis model (CFA) is a process that allows researchers to use multiple indicators to obtain 
an exogenous latent variable or an endogenous variable called a latent factor or latent construct. Each latent variable has various sizes or indicators. Selection of indicators and determination of each latent factor is made based on theories or studies conducted before this. With this CFA model, the researcher must first determine the number of desired factors in a set of latent variables and in which factor each of these indicators will be included before running the analysis. The CFA will show the extent to which the factor specifications predicted by the researcher correspond to the actual reality. In other words, CFA is a tool that allows us to accept or reject the existing theory.

In the form of equations, the theory of factor attestation may be represented by several equations as follows:

$$
\begin{aligned}
& x_{1}=\lambda_{\mathrm{x} 11} \xi_{1}+\delta_{1} \\
& x_{2}=\lambda_{\mathrm{x} 22} \xi_{2}+\delta_{2} \\
& \cdot \\
& \cdot \\
& \cdot \\
& x_{n}=\lambda_{\mathrm{xn}, \mathrm{n}} \xi_{\mathrm{n}}+\delta_{\mathrm{n}}
\end{aligned}
$$

Where,

$$
\begin{array}{ll}
x_{1} \ldots x_{n} & =\text { indicators that define construct } \\
\xi 1 \ldots \xi \mathrm{n} & =\text { construct specified by indicator } \mathrm{x} \\
\lambda_{\mathrm{x} 11 . .} \lambda_{\mathrm{xnn}}= & \text { 'path' representing the relationship between latent factor }(\xi 1) \text { and the } \\
& \text { determinant variable }(\mathrm{x} 1) . \\
& =
\end{array}
$$

This model of determination involves constructs with no causality and correlation between them. This model only calculates covariant estimation by using equations that represent the theory to be tested. This covariance matrix is then compared to the actual covariance matrix calculated from the indicator data. This determination model is said to be worth it if both covariance matrices are almost identical. Latent variables are associated with indicators through measurement models in the form of factor analysis. Each latent variable is modeled as a factor that underlies the related indicator [7]. Factor loading (factor loading) that connects latent variables with known indicators is labeled $\lambda$ ("lambda"). The error in the measurement model is denoted by $\xi$ (ksi). The measurement model can be illustrated in Figure 1.

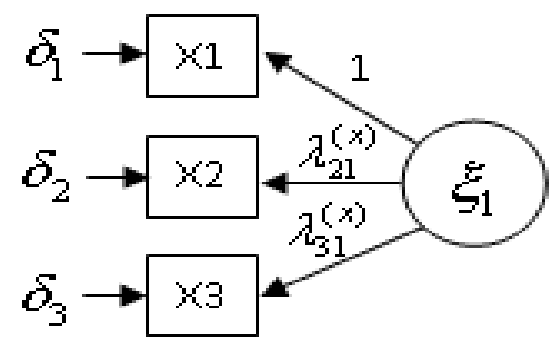

Fig. 1 SEM measurement model.

In this study using latent factor that is the achievement of farmer's life result, that can be seen in Figure 2 below. MPF is also used to know the definitive determinants to the farmers' livelihoods in Aceh. 


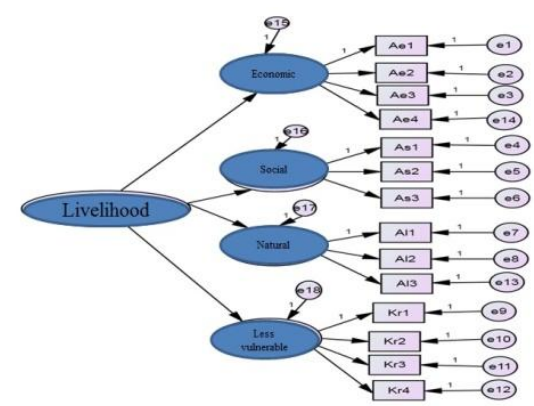

Fig. 2 Hypothesis of outcome livelihood of farmers.

\subsection{Economic aspects}

The Figure 3 shows the determination for achievement of farmer's life outcome rather than economic aspect and the model is determined by three indicators ie $A_{1}, A_{2}, A_{3}$ and $\mathrm{Ae}_{4}$. This indicator depends on the latent variable ( $\left.\eta \mathrm{e}\right)$ and the vector determination vector, $\mathrm{e}_{1}$, $\mathrm{e}_{2}, \mathrm{e}_{3}$ and $\mathrm{e}_{4}$.

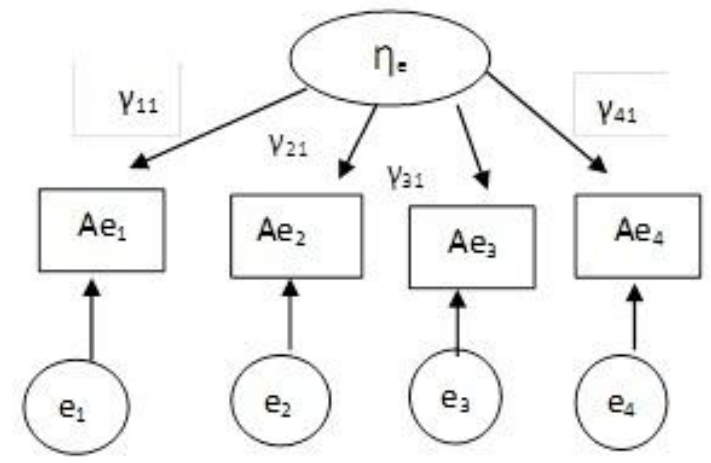

Fig. 3 The hypothesis of the model for outcome of Livelihood from the economy aspect.

This model may be written as follows:

$$
\begin{aligned}
& \mathrm{Ae}_{1}=\gamma_{11} \eta_{\mathrm{e}}+\mathrm{e}_{1} \\
& \mathrm{Ae}_{2}=\gamma_{21} \eta_{\mathrm{e}}+\mathrm{e}_{2} \\
& \mathrm{Ae}_{3}=\gamma_{31} \eta_{\mathrm{e}}+\mathrm{e}_{3}
\end{aligned}
$$

Where,

$\mathrm{Ae}_{1}=$ Farmers' perception that income is increasing

$\mathrm{Ae}_{2}=$ Farmers' perception that deposits are increasing.

$\mathrm{Ae}_{3}=$ Farmers perception that there is an increase in the sale of agricultural products

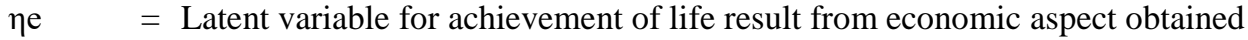
by farmer

$\gamma_{11}-\gamma_{31}=$ The coefficient that explains the effect of latent variables for the achievement of life's life from the economic aspect that the farmer receives on indicators Ae1, Ae2 and Ae3

$\mathrm{e}_{1}, \mathrm{e}_{2}, \mathrm{e}_{3}=$ Fixed determination for indicator $A \mathrm{e}_{1}, \mathrm{Ae}_{2}$, and $\mathrm{Ae}_{3}$ 


\subsection{Social Aspects}

This figure 4 shows the determination for achievement of farmer's life result from social aspect and this model is determined by three indicators ie $\mathrm{As}_{1}, \mathrm{As}_{2}$, and $\mathrm{As}_{3}$. This indicator depends on the variable attenuation ( $\eta \mathrm{s}$ ) and the vector determination, $\mathrm{e}_{5}, \mathrm{e}_{6}$, and $\mathrm{e}_{7}$.

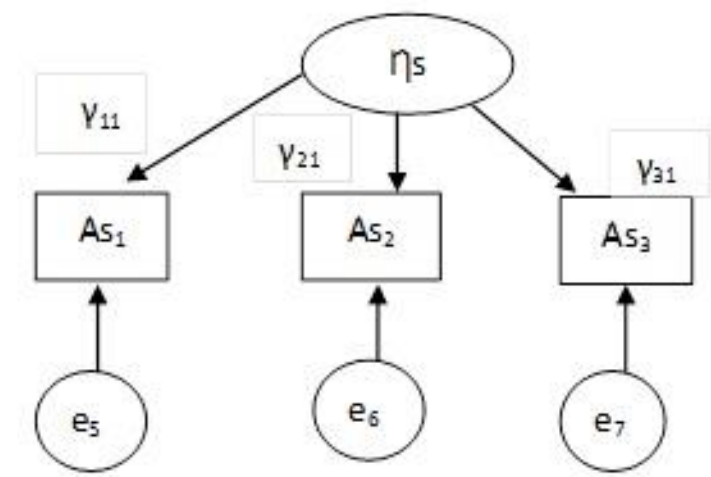

Fig. 4 The hypothesis of the model of outcome livelihood from the social aspect.

In mathematical equations, this model may be written as follows:

$$
\begin{aligned}
& \mathrm{As}_{1}=\gamma_{11} \eta_{\mathrm{s}}+\mathrm{e}_{5} \\
& \mathrm{As}_{2}=\gamma_{21} \eta_{\mathrm{s}}+\mathrm{e}_{6} \\
& \mathrm{As}_{3}=\gamma_{31} \eta_{\mathrm{s}}+\mathrm{e}_{7}
\end{aligned}
$$

Where,

$\mathrm{As}_{1}=$ Perception of farmers on social relations of society is getting better

$\mathrm{As}_{2}=$ Peasant perception of participation in unity as an effort to increase knowledge

$\mathrm{As}_{3}=$ Farmers' perceptions of participation in various religious social activities in residential areas such as recitation and congregational prayers.

$\eta \mathrm{s}=$ Latent variable for capain of life result from social aspect obtained by farmer.

$\gamma_{11}-\gamma_{31}=$ The coefficient that explains the influence of latent variables for the capain of the life result from the social aspect that the farmer receives on the indicators of As1, As2, and As3.

$\mathrm{e}_{5}, \mathrm{e}_{6}, \mathrm{e}_{7}=$ Fixed determination for indicators $\mathrm{As}_{1}, \mathrm{As}_{2}$, and $\mathrm{As}_{3}$.

\subsection{Natural Aspect}

This Figure 5 shows the determination for achievement of farmer's life outcomes from the natural aspect and this model is determined by three indicators namely $A_{11}, A_{12}$ and $A_{13}$. This indicator depends on latent variables $\left(\eta_{1}\right)$ and vector determination definition, $e_{8}, e_{9}$ and $e_{10}$. 


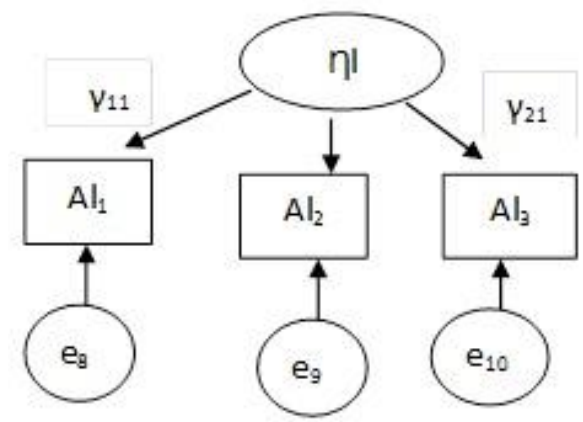

Fig. 5 The hypothesis of the model of outcome livelihood from the natural aspect.

In mathematical equations, this model may be written as follows:

$$
\begin{aligned}
& A_{11}=\gamma_{11} \eta_{1}+e_{8} \\
& A_{12}=\gamma_{21} \eta_{1}+e_{9} \\
& A_{13}=\gamma_{31} \eta_{1}+e_{10}
\end{aligned}
$$

where,

$\mathrm{A}_{11}=$ Farmers perception of mangrove cultivation near coast and water supply in the effort of natural guarding around

$\mathrm{A}_{12}=$ Farmers perceptions about the use of steel and toxins and fishing gear

$\mathrm{A}_{13} \quad=$ Farmers perceptions of participation in mutual assistance activities as an effort to preserve the natural environment.

$\eta \mathrm{s}=$ Latent variable for the achievement of life result from the surrounding natural aspect

$\gamma_{11}-\gamma_{31}=$ The coefficient that explains the influence of latent variables to achieve life outcomes from the natural aspects around with indicators $A_{11}, A_{12}$, and $\mathrm{A}_{13}$.

$\mathrm{e}_{8}, \mathrm{e}_{9}, \mathrm{e}_{10}=$ Fixed determination for indicators $\mathrm{A}_{11}, \mathrm{~A}_{12}$, and $\mathrm{A}_{13}$.

\section{RESULTS AND DISCUSSION}

MPF is also used to know the definitive determinants to the achievements of farmers' livelihoods in Aceh. Figure 6. shows the model for the latent variables of the outcome of life. There are various indicators that represent every aspect of the outcome of life. This aspect summarizes the economic, social, and natural aspects and diminishes the vulnerability and is called construct. A factor validation (MPF) analysis will be carried out to test each dimension of a life-size aspect variable that has been known for certain based on previous research. The estimation was done by using the maximum likelihood (MLE) method to estimate 14 indicators of the four constructs of life outcome outcomes established. Figure 6 shows the model 1 hypothesis of validating factors for the achievement of life outcomes.

The result of model 1 analysis found that the value of $\chi 2$ (CMIN) is 240.494 with a freedom 75 freedom and an opportunity value of 0.000 . In addition, other caliber values have also reached the recommended values. The value of CMIN / DF $=3.207$ is more than 1 and less than 5 as suggested, GFI value $=0.939$, AGFI $=0.915, \mathrm{NFI}=0.884, \mathrm{RFI}=0.859, \mathrm{IFI}=$ $0.917, \mathrm{TLI}=0.899, \mathrm{CFI}=0.917$. recommended, and the value of RMSEA $=0.063$ is less than 
0.1 as suggested. These results indicate the correspondence of data with the hypothesized model is good.

However, to increase the value of model density an MI analysis is required for this model. The research of MI values performed in the covariance section first implies the maximum MI value of 40,732 lies in the parameters connecting e10 with e12, indicating a two-way relationship between these variables.

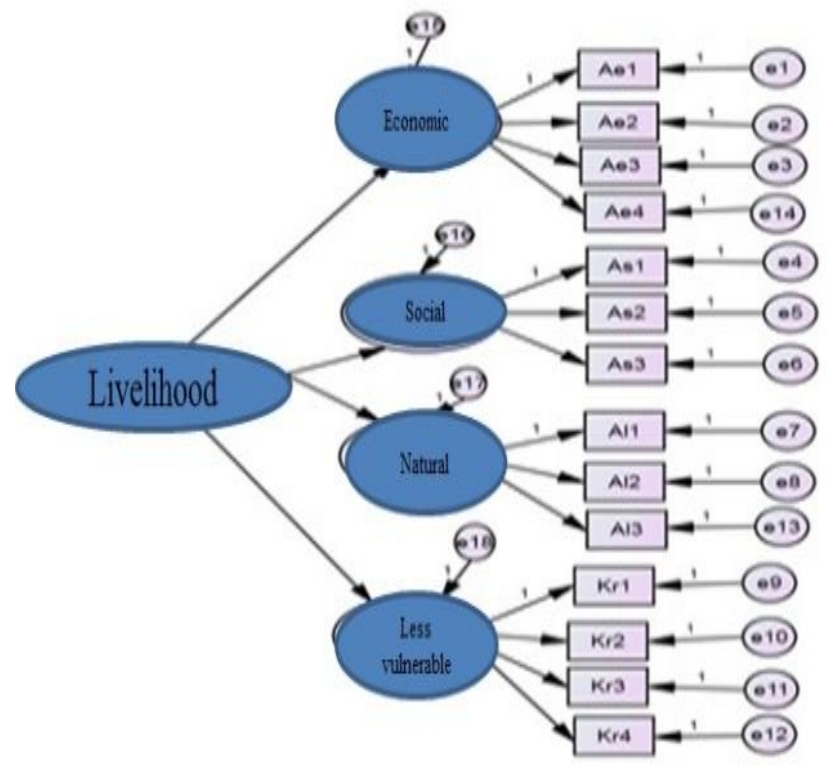

Fig. 6 Model 1 determination factor of outcomes livelihood.

This model 1 is estimated again by placing a line of two arrows to the variables e10 and e12 and this model is called model 2 (Figure 7). The value of MI is intended if the model is reexamined by determining the parameter e 10 with e 12 as free, the value of $\chi 2$ will decrease by 40,732 , and the budgeting value is about 0.233 (par change value). This information suggests that if there is a greater variety of farming tools available to farmers it will make it easier for them to get more crops, so that this will strengthen their economic status and ultimately help them to stay out of debt. Based on the above rationales, then model 1 must be retested.

However, according to Joreskog [8], having a factor load value of less than 0.3 must be removed from the analysis to obtain a good model equivalence. In this model the variables As1, Al2 and $\mathrm{Kr} 3$ have a low coefficient value that is $0.101,0.213$ and 0.181 . Thus, this model is initially budgeted by removing the transformers As1, Al2 and $\mathrm{Kr} 3$ and called model 2 (Figure 7). As1 variable is an indicator of farmer's participation in unity, Al2 also an indicator of farmer's participation to cooperate cleaning village as effort to preserve nature around. When a $\mathrm{Kr} 3$ converter is an indicator of more work available. Yet all of these indicators are found to be unable to explain the constructs of social aspects, the surrounding natural aspects and diminished aspects of vulnerability.

Based on the above statement, then the original budgeted model. The results of the analysis on model 2 found that the value of $\chi 2$ (CMIN) was reduced to 129.152 with a freedom slice of 41 and a value of 0.000 . In addition, other equivalence values also exceed the 
suggested value. The value of CMIN / DF $=3.150$ is more than 1 and less than 5 as suggested. The value of GFI $=0.957, \mathrm{AGFI}=0.932, \mathrm{NFI}=0.934, \mathrm{RFI}=0.911, \mathrm{IFI}=0.954, \mathrm{TLI}=0.938$, CFI $=0.954$ exceeding 0.90 as suggested, and RMSEA $=0.062$ less than 0.1 as suggested These results indicate the correspondence of data with the hypothesized model is good. Thus, Model 2 is modeled as the final model for the beneficiary of life sustainability and is used for the following structured equation model.

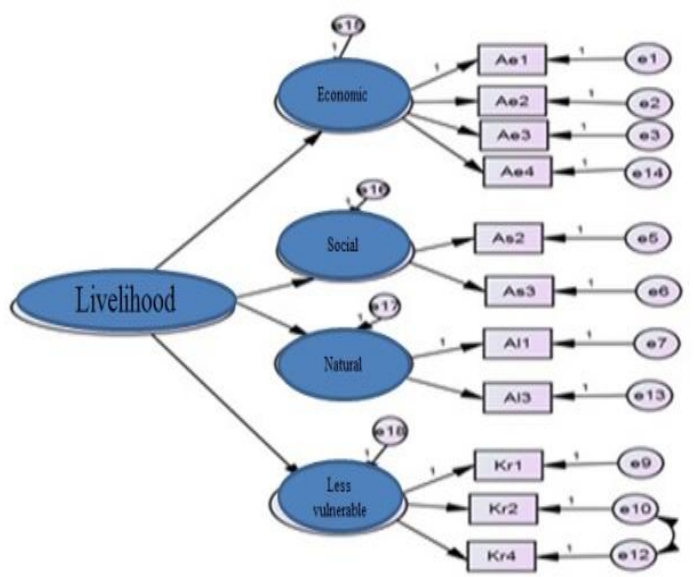

Fig. 7 Model 2 endorsement of factors for life outcomes

The results of model 2 analysis can also be seen in Table 1 which shows the regression value that all factor loading values are above 0.5 and all $\mathrm{P}$ values (probability) are significant at $\alpha=1 \%$ and this indicates that all indicators can explains the existing constructs. Therefore, Model 2 is used as the final model for the beneficiary to change the achievement factor of living results and used for the following structured equation model.

Table 1. Regression Weight the indicator of outcome livelihood of the farmers

\begin{tabular}{cccccc}
\hline Indicator & Coeficien & S.E & C.R & P & Loading Factor \\
\hline Social <-- Outcome livelihood & .066 & .053 & 1.232 & .218 & .353 \\
Natural <-- Outcome livelihood & 2.345 & .324 & 7.239 & $* * *$ & .994 \\
Economic <-- Outcome livelihood & .532 & .058 & 9.101 & $* * *$ & .962 \\
Less vulnerable <-- Outcome livelihood & .958 & .026 & 7.327 & $* * *$ & .991 \\
Ae2 <-- Economic & .960 & .130 & 7.409 & $* * *$ & .503 \\
Ae3 <-- Economic & 1.430 & .183 & 7.837 & $* * *$ & .548 \\
As2 <-- Social & 2.941 & .426 & 6.904 & $* * *$ & .996 \\
As3 <-- Social & .340 & .049 & 6.904 & $* * *$ & .501 \\
A11 <-- Natural & 4.025 & .667 & 6.039 & $* * *$ & .983 \\
Kr1 <-- Less vulnerable & 2.072 & .255 & 8.137 & $* * *$ & .921 \\
Kr2<-- Less vulnerable & .560 & .068 & 8.246 & $* * *$ & .502 \\
Ae4 <-- Economic & 1.631 & .190 & 8.573 & $* * *$ & .711 \\
A13<-- Natural & .211 & .039 & 5.468 & $* * *$ & .495 \\
Kr4<-- Less vulnerable & .478 & .059 & 8.072 & $* * *$ & .536 \\
Ae1 <-- Economic & 1.030 & .144 & 7.146 & $* * *$ & .504 \\
\hline
\end{tabular}

Table 1 describes the results of an analysis that indicators of income, savings, sales of crops, and wellbeing can explain the constructs of economic aspects. When the social aspects 
of the construct can only be explained by two indicators namely social relations society and social activities that the better religion. The surrounding natural constructs can only be explained by two indicators, namely using fishing equipment as recommended and participating in the effort to plant the mangrove near the beach. For farmers also using fertilizers and pesticides according to advice and participate in cleaning water channels, especially when the rice planting season. Constructive reduced vulnerability is also only able to be explained by only three indicators that have skills other than farmers and fishermen, have a variety of agricultural tools, and do not have debt bonds with agents / traders.

The results of this study are slightly different from those of Roslina [9] and Nor Diana [10] which also uses structured equation models and analyzes the socio-economic and natural impacts with a sustainable approach to life. But basically these three impacts are indicators rather than achievement of farmers' livelihoods. For example the positive impact on the economic aspects such as increased income, increased sales and increased welfare. Social aspects also use indicators of community participation in farmer groups. When Sahri et al. [11] uses two indicators to explain the fisherman's life outcomes, which are increasing incomes and social relationships in society are getting closer.

It also illustrates that the higher the financial stages in the form of savings and access to finance, and the higher the stage of ownership of agricultural equipment and the better the social and cultural development of the community both in the form of work motivation and the stronger the influence of customary law, the higher the stage of this strategy by farmers. Sahri, et.al. [11], Roslina [9], Widodo [12], in their study found no distinction that is the relationship between vulnerability and life strategy with the outcome of livelihood.

\section{CONCLUSION}

Based on the results of research that has been done by using the attestation analysis of achievement factor of the farmer's life is the second model is a model that shows the correspondence of data with the model hypothesized is good. Therefore, Model 2 is used as the final model for the achievement of farmers' life result. It also shows that all factor loading values have numbers above 0.5 and all $P$ values (probability) are significant at $\alpha=1 \%$. The $P$ value is 0,000 which is well below 0.05 which indicates that all indicators can explain the existing constructs.

\section{REFERENCES}

[1] UNDP, “Aceh Partnerships for Economic Development (APED): Annual Progress Report 2009," Aceh, 2010.

[2] I. Agussabti and S. Tripa, “Aceh Post Tsunami Recovery Status Report Project-Livelihood Cases," Jepang, 2012.

[3] DFID, "Sustainable livelihoods guidance sheets," London, 1999.

[4] F. Ellis, "The determinants of rural livelihood diversification in developing countries," J. Agric. Econ., vol. 51, no. 2, pp. 289-302, 2000.

[5] J. F. Hair, W. C. Black, B. J. Babin, R. E. Anderson, and R. L. Tatham, "Multivariate data analysis . Uppersaddle River.” NJ: Pearson Prentice Hall, 2006.

[6] S. Santoso, Konsep dan Aplikasi dengan AMOS. Elex Media Komputindo, 2011.

[7] D. Andriani, "Pengenalan Structural Equation Modeling," 2013. [Online]. Available: 
http://magisterakutansi.blogspot.com/2012/11/pengenalan-structural-equation-modeling.html. [Accessed: 10-Oct-2012].

[8] K. G. Jöreskog and D. Sörbom, LISREL 8: Structural equation modeling with the SIMPLIS command language. Scientific Software International, 1993.

[9] K. Roslina, "Pembangunan Akuakultur di Kedah: Analisis Impak Ekonomi, Sosial dan Alam Sekitar Menggunakan Pendekatan Kehidupan Lestari,” Institut Alam Sekitar dan Pembangunan, Universiti Kebangsaan Malaysia, 2009.

[10] M. I. Nor Diana, "Kajian Impak Projek Pembangunan Pertanian Bersepadu (IADP) Samarahan, Sarawak: Analisis Sosioekonomi dan Alam Sekitar," Institut Alam Sekitar dan Pembangunan, Universiti Kebangsaan Malaysia, 2011.

[11] M. Sahri, Mashudi, and E. G. Sukoharsono, "Analisis Faktor-Faktor yang Mempengaruhi Aksesibilitas Sosial Ekonomi Nelayan Kecil di Jawa Timur," J. Ilmu Sos., vol. 18, no. 1, pp. 43-55, 2011.

[12] S. Widodo, "Strategi nafkah berkelanjutan bagi rumah tangga miskin di daerah pesisir," HubsAsia, vol. 10, no. 1, 2011. 